\title{
Rereading of the Quran in Light of Nursi's Risale-i Nur Collection: Shuhudi Exegesis
}

\author{
Salih Yucel 1,2
}

Citation: Yucel, Salih. 2021.

Rereading of the Quran in Light of Nursi's Risale-i Nur Collection: Shuhudi Exegesis. Religions 12: 1088. https://doi.org/10.3390/rel12121088

Academic Editors: Ismail Albayrak Hakan Coruh and Susanne Olsson

Received: 20 November 2021

Accepted: 7 December 2021

Published: 9 December 2021

Publisher's Note: MDPI stays neutral with regard to jurisdictional claims in published maps and institutional affiliations.

Copyright: (C) 2021 by the author. Licensee MDPI, Basel, Switzerland. This article is an open access article distributed under the terms and conditions of the Creative Commons Attribution (CC BY) license (https:// creativecommons.org/licenses/by/ $4.0 /)$.
1 Centre for Islamic Studies and Civilisation, Charles Sturt University, Bathurst, NSW 2795, Australia; salih.yucel@acu.edu.au

2 Faculty of Theology and Philosophy, School of Theology, Australian Catholic University, Melbourne, VIC 3002, Australia

\begin{abstract}
The concept of tafsiri şuhudi (transempirical exegesis) was coined for the first time by Said Nursi (d. 1960) and was reflected throughout his works. In his tafsiri şuhudi (pronounced shuhudi) methodology, Nursi views the Qur'an as an interpretation of the universe, that is Kitab al-Kabir (a big book). According to Nursi, such an exegesis is needed to reach the degree of iman tahkiki (investigative belief), also known as authentic faith. As part of his methodology, Nursi uses spiritual experience (kashf) and secular sciences as evidence for gaining true faith. Tafsiri şuhudi is an offshoot of ishari (inner meaning) tafsir but one that is injected with rationalism. This tafsir type also injects witnessing (şuhudi) into the dry body of scientific and modern tafsir that emerged in the Muslim world after European enlightenment. This article first examines the original hermeneutical concept of tafsir şuhudi in Nursi's works and then analyses the sound heart, an essential part of iman tahkiki, in light of Nursi's transempirical experience. The article argues that Nursi injects rationalism into the ishari tafsir methodology and infuses şuhudi experience by making it not only an epistemic but also an existential understanding of modern tafsir methodology.
\end{abstract}

Keywords: tafsir; Said Nursi; Quranic exegesis; tafsir şuhudi; modern tafsir; Qur'an

\section{Introduction}

The Qur'an is the most important sacred text for Muslims. It is a guide and focuses on gaining eternal happiness without neglecting humans' worldly life. To understand the Qur'an, Muslim scholars have developed various types of tafsirs (Qur'anic exegeses). During the classical period of Qur'anic exegesis, narrative (riwayah) or tradition, opinion (dirayah), theological (kalamic), linguistic, juristic, ishari (inner meaning), and, finally, scientific tafsirs emerged. Each of these tafsirs responded to the spiritual, social, theological, and juristic needs of Muslim societies due to the expansion of Islam in different regions. Those who converted to Islam brought their theological and philosophical questions with them and sought to have them answered through their understanding of the Qur'an. During the formation period of Islamic sciences, there was a need for narrative based tafsir that depended heavily on the interpretation of the Qur'an by the Qur'an, then by prophetic traditions (hadith), or by the opinions of the companions and their successors (Çoruh 2019a).

From the tenth century onward, the influence of the Hellenistic philosophy in Muslim lands resulted in reason based and linguistic tafsirs that predominantly made rational arguments in their commentaries on the verses and different meanings of the words of Qur'anic verses. The emergence of various groups and sects caused the birth of theological tafsirs. Later, when zuhd (asceticism) and piety gradually declined, in response to a lack of spirituality, ishari tafsirs appeared. For a long time, these different perspectives lived in tafsirs side by side; sometimes they became independent genres. When Muslims faced the challenge and felt the influence of the European Enlightenment, Muslim scholars 
developed a scientific or modern tafsir to mitigate the domination of this new development (Coruh 2019b).

Although Nursi's commentary can be considered a modern tafsir, it departs from typical methodology by infusing şuhudi (transempirical) interpretation in his exegetical works called Risale-i Nur. This type of tafsir is one of the methods of the interpretation of Qur'anic exegesis that was not mentioned as a term in any exegetical works before Nursi (Çoruh 2019a). The concept of tafsiri şuhudi was first coined by Nursi (Ozgel 2015). Coruh defines tafsir şuhudi as "clarification of comprehensive expressions of the Qur'an by visible and experiential phenomena" (Çoruh 2019a, p. 55). Tafsiri şuhudi can be considered a response to materialistic philosophy which argues that religions are products of humans and denies the supernatural world (Vasquez 2011).

For Nursi there are two types of Qur'anic commentaries:

"The first is the well-known sort of commentary. Commentaries of this sort expound and elucidate the Qur'an's phraseology, words and sentences. The second sort explains, proves and elucidate with powerful arguments the Qur'an's truths related to belief. This sort has great importance. Sometimes the wellknown, externalist commentaries include this sort in summary fashion. But the Risale-i Nur has made it its basis directly and is a commentary on the Qur'an's meanings." (Nursi 2010, p. 513)

Nursi identifies his works Risale-i Nur as tafsiri ma'nawi (spiritual tafsir). Many scholars view reasoning (aql) and spirituality as complementary (Nursi 2008). That is, they do not choose one type over another. This is the position of al-Ghazali (d. 1111), Imam Rabbani (d. 1624), and reinstated more recently by Nursi.

This paper argues that Nursi developed the tafsiri şuhudi to interpret some Quranic verses by injecting rationalism to the understanding of the Qur'an in response to attacks of materialistic philosophy in the 20th century. It is worth noting that Nursi experienced zawqi shuhud (the pleasurable spiritual state of witnessing) not only by soul but also with reason. He does not drown in şuhudi istighraq (state of ecstasy or absorption) like Ibn Arabi (d.1240) and Nursi's rationalism does not take precedence over spirituality like Ibn Sina (d.1037). Nursi is like Rumi, for whom "intellect and reason are necessary but not sufficient conditions for transformative action". However, he departs from Rumi who "sells reason and mind and buys excitement" (Yucel 2017, p. 548) to gain the level of shuhud. It can be said that Nursi brings şuhudi ma'rifa (transempirical knowledge) to a level that the lay person can comprehend.

\section{The Concept of Shuhud}

The concept of shuhud/wahdat al-shuhud has existed in Islamic literature in its tentative (or primitive form), particularly in Sufism, since the first century of Islam. Some companions of the Prophet, such as Abu Hurayra, used shuhud in their sayings (al-Qushayri 2007). Al-Qushayri elaborates on how shuhud was understood by great Sufi scholars in the first four centuries of Islam (p. 298). However, as a concept, first, shuhud was formulated by Ala'udawla Simnani (d.1336) (Weismann 2007). Al-Qushayri defines shuhud as "to be in the presence of the Absolute Truth" (al-Qushayri 2007, p. 98), namely God Himself. For Muhammad b. al-Husayn, reaching the level of witnessing "first requires knowledge (ma'rifa), second conformation (tasdiq), third sincerity (ikhlas) and then witnessing (shuhud)" (p. 194). Imam Rabbani defines shuhud as witnessing with the inward or inner realm (Imam Rabbani 2014) or "gaining experiential knowledge directly. It is often used synonymously with the unveiling, i.e., kashf or mukashafa" (Alam 2010, p. 62). Shuhud can be through reflecting, knowing, seeing, and conceiving (p. 79). According to Imam Rabbani, shuhud can be experienced at the spiritual state of ecstasy (Imam Rabbani 2014). Shuhud is the degree of "haqqa'l-yaqin", which means the final level of certainty by which someone can gain the truth through kashf (spiritual experience) (Imam Rabbani 2014, p. 50). Imam Rabbani employs Tawhidi Şhuhudi (Witnessing Ones of God) in response to Ibn Arabi's Wahdat al-Wujud (the Unity of Existence) (Faruque 2016). 
Before analysing Nursi's tafsiri şuhudi methodology, it is essential to know the context of his writing. Nursi's commentary is not only the product of intellectualism but also suffering and devotion. Nursi witnessed the colonisation of the Muslim world, the collapse of the Ottoman Empire, the abolishment of the Caliphate, the closure of all religious educational institutions, Sufi orders and lodges, and the replacement of Islamic jurisprudence with European law by the leaders of the Republic of Turkey (Saritoprak 2008a, 2008b). The new republic was established on principles of Jacobin secularism and Turkish ultra-nationalism. Teaching the Qur'an and anything in Arabic script was banned. A law requiring the wearing of European hats was implemented. The people of the Rize region resisted the hat law and the region was bombed by warships (Yucel 2018). Many Christians and Jews fled or left Turkey due to a lack of freedom or an oppressive regime. The influential religious scholars and leading figures were seen as a threat to the new regime. Some of them were executed while others were imprisoned or sent into exile. Nursi was exiled to Barla, a small town where he could not travel to even a nearby village and was not allowed to have any visitors. He was under the surveillance of the intelligence service until he died. Many lawsuits were filed against him. The prosecutors asked for the death sentence, claiming that Nursi intended to bring shari'a law to Turkey, resulting him in being imprisoned for many years. It is indicated in his biography that he was poisoned eighteen times (Nursi 2007a). For such a tumultuous period, Nursi believed that he had no time to think of himself (Keskin 2019) and dedicated his life to writing books on faith.

\section{Nursi's Methodology of Şuhudi Tafsir}

Nursi's methodology of Qur'anic interpretation is not like narrative based tafsir, which explains verses by other verses or hadiths or scholarly points of view. Although to a certain extent it resembles reason based tafsir, Nursi includes şuhudi analysis in his exegetical works. His tafsir, unlike other tafsirs, focuses only on approximately 620 verses that are related to tawhid (unity of God), nubuwwah (prophethood), hashr (resurrection), adalah (justice), and ibadah (worship) (Ozgel 2015). Nursi employs reason, logic, and şuhudi experience for persuasion, with logical evidence. Instead of focusing on the literal meaning of the verses, he instead delves into the deep spiritual meaning of the verses (Ansari 2017). Nursi aims to respond to the doubts raised by materialistic philosophy about God, prophethood, resurrection, justice, and worship.

Furthermore, Nursi focuses on tanasub (thematic unity) between verses of the Qur'an and its words like Fakhr Din al-Razi (d.1210) did. He sometimes defines linguistic meanings of words of the Qur'an like Zimakhshari (d.1144) and extracts rulings from the verses and words similar to al-Qurtubi (d.1273) (Nursi 2007c). He comments on Surah al-Fatiha (Chapter of Opening) like al-Qushayri (d.1074), Najm al-Din Kubra (d.1221), and Ismail Haqqi Bursawi (d.1715) in his şuhudi exegetical work (Nursi 1996, 2007c).

In his works Nur Aleminin bir Anahtari and Sozler, Nursi employs şuhudi methodology for interpretating the verse (Qur'an, 17:1) related to Ascension of the Prophet by combining reason and spirituality. Unlike other tafsirs, he does not focus on the narrative detail of ascension but instead on its philosophical and inner meaning (Nursi n.d., 2005). First, Nursi discusses the ascension from reason perspective, after which he delves into his şuhudi experience.

In my view, one of the best examples of tafsiri şuhudi in his works is about the Chapter of Opening. In relation to this chapter, Nursi's experience is as follows: once, while he was praying in the congregation at Bayezid Mosque, he pondered over the use of the first person plural in the verse, "You alone do we worship and from You alone do we seek help" (Qur'an, 1:4). Nursi wanted to understand the wisdom behind the use of "we" instead of "I" in this verse. In response to this he explains how the mystery and virtues of performing the prayers in the congregation was unfolded to him and how the congregation which he was part of was separated into three circles.

The First Circle was the vast congregation of believers and those who affirm Divine Unity on the face of the earth (Nursi 2010, p. 585). Nursi observed the world of Islam 
become like a huge mosque and Ka'ba was the mihrab (altar) (Nursi 2010, p. 586). All the congregations were repeating the above verse like him. Nursi continues:

"The Second Circle: I looked and saw that I was part of a congregation consisting of all beings, all of which, performing prayers and glorification, were occupied with the benedictions and glorification particular to its group and species. Their worship consists of the activities we observe, called 'the duties of things.' Declaring: 'God is Most Great!' before this, I bowed my head in wonderment and looked at myself. Within a Third Circle, I saw an astonishing microcosm which was apparently and in quality small, but in reality, number, and duties, great. This, from the particles of my being to my external senses was a congregation in which every group was occupied with duties of worship and thanks ...". (Nursi 1996, pp. 461-62)

This was an experience Nursi had, an experience that helped him, and the reader of his works, understand why the Qur'an states, "You alone do we worship" instead of "You alone do I worship", making it a perfect example of being a tafsiri şuhudi.

It is interesting to note that Nursi employs logic in commenting on verses related to the resurrection (Qur'an, 30:50) and the afterlife (Nursi 2005) like al-Ghazali (d.1111) and Sa'ad al-Din al-Taftazani (d.1390). In explaining the miracles of the Prophet Muhammed, Nursi's work resembles narrative based tafsirs like Muhammed ibn Jarir al-Tabari (d.923). However, he comments on each narrative from spiritual, sociological, and logical perspectives.

Nursi departs from modern tafsirs despite giving a place to reason in his works. He uses secular sciences for commenting on some Quranic verses, but adds spirituality. However, he never claims that the scientific explanation is the absolute meaning of the verse. Nursi does not use reason for the sake of argument, but more for persuasion and intellectual satisfaction. In his tafsiri şuhudi, he astonishes the reason, heart, and soul with spiritually injected intellectual pleasure. Nursi sometimes even employs secular sciences in tafsiri şuhudi for persuasion of the mind and not imaginary things. To gain şuhudi knowledge through experience, he submits his minor will (irada-i juziyya) to the Absolute Will of God (irada-i kulliyya) (Nursi 2009). In his exegetical work, Nursi is critical of literalists. He also argues that some of the Isra'iliyyat narratives are from unreliable Christian and Jewish sources (Nursi 2008).

Nursi asserts openly that his works are the şuhudi commentary of the Qur'an (Nursi 2007b). It is important to note that Nursi uses two meanings with the concept of shuhud. The first is that wahdat ash-shuhud (the concept of the unity of vision) sees tawhid or Oneness of God at the degree of apparentism or witnessing in contrast to wahdat al-wujud, the Unity of Existence, which is a controversial point of view of Ibn Arabi. Secondly, Nursi interprets the Qur'an for witnessing the Oneness of God through everything in the universe. In the aspects of tafsir şuhudi that lead to acceptance of the articles of the faith, which is the realm of the world, with a belief close to consciousness (Ozgel 2015), Nursi's aim is to turn the reader from blind faith to true faith at the degree of şuhudi.

Although Nursi accepts the authority and the validity of tafsir traditions (Çoruh 2019a), he departs from others in tafsiri şuhudi. Other commentators, such as al-Qushayri and Bursawi, try to uplift the reader in suluk (spiritual journey) with heart and soul for experiencing and understanding the inner meaning of the verses of the Qur'an. Nursi brings şuhudi knowledge and experience to a level of reason that is much easier for all levels of society to understand. For Nursi, this method reduces the risk of deviation and misunderstanding. He asserts that "the Qur'an witnesses human nature "(Nursi 2010, p. 126). Nursi does not contradict the literal meaning but delves into understanding the verses' wisdom or deeper meaning by bringing the universe into the light of readers' perceptions.

Nursi is not the first one who commented on verses from a şuhudi perspective. However, he is the first to use this concept and establish it with the combination of mind and heart at the level of the lay person. Previous scholars' şuhudi interpretations address the spiritual elite and are highly difficult to comprehend by reason. Some of these interpreta- 
tions are even considered a deviation from Islamic aqida (doctrine) by traditionalists and theologians.

For Nursi, everything in the universe is like perfect art and shows its Maker (As-Sanii). Everything in the universe is also an interpretation of the Qur'anic verses because the Qur'an is Kitab al-Saghir and the universe is Kitab al-Kabir. Therefore, he uses secular science as evidence of gaining true faith (iman tahkiki), contrary to some philosophers who use science against religion. Nursi argues that there are no conflicts between science or scientific discoveries and Islam. He states that "all sciences you study continuously speak of God and make known the Creator, each with its own particular tongue ... " (Nursi 2010, p. 226).

In this section, the dynamics and characteristics of Nursi's understanding of tafsiri şuhudi will be analysed. Although there are different viewpoints, to the best of my knowledge, it is possible to summarise these features into seven parts.

The first one is a comprehensive (mahruti) outlook of the verses within the theological and shari'a principles by employing heart and mind to gain transempirical knowledge, unlike Ibn Arabi, who goes beyond Islamic doctrine to a degree of spiritual intoxication. Although Nursi does not reject Ibn Arabi's views altogether, he is cautious since Ibn Arabi's approach sometimes does not match the authentic perception of Islam.

Second, Nursi is insistent and consistent in his interpretation of the "verses by associating them with the visible events and experiments in the physical world "(Çoruh 2019a, p. 53). He interprets the Qur'anic verses with the "Book of the Universe" (Kitab al-Kabir). He views the signs of creation in the universe like evidence from the Qur'an. He continues, "Know, o friend, that just as the Qur'anic verses interpret each other, the parts of the Book of the Universe also interpret each other" (Nursi 2007b, p. 193). To Nursi, the signs of creation in the universe reflect the Qur'an and the Qur'an reflects the signs of the universe (Ozgel 2015). For Nursi, everything in the universe points to the Maker. He says, "The Qur'an is the pre-eternal translator of the mighty book of the universe; the post-eternal interpreter of the various tongues reciting the verses of creation..." (Nursi 2007c, p. 16). It can be said that Nursi views the Qur'an and the universe as two sides of one coin. Both explain the concept of Unity and Oneness of God, resurrection, prophethood, and justice. By examining the signs of the universe, on the one hand, he wants to refute materialistic philosophy. On the other hand, he aims to persuade believers logically to gain true faith. Thus, in his exegetical methodology, reason and spirituality go hand in hand.

Regarding tafsir şuhudi, there are hundreds of examples in his works. He uses many visible things in the universe. For example, Nursi says:

Planting seeds in an arable land indicates that the land is controlled by the owner of the seeds, and that the seeds belong to the one who controls the land. All universal elements [like water, air, and soil, which imply an all-encompassing knowledge and wisdom] are at the disposal of a single Maker. Their simplicity, uniformity, and comprehensiveness, and all the things "planted" in them (i.e., fruits of Mercy, miracles of Power, and words of Wisdom), as well as their worldwide distribution for certain purposes, are evidence that the comprehensive and comprehended, as well as the "land" and the "seeds" planted in it, are controlled by God. (Nursi 2007b, p. 11)

Through such examples, it can be said that Nursi aims to prove that God's word does not contradict the works of God, as Sir Syed Ahmad Khan (d.1898) argues (Saeed 2008). Furthermore, he wants to guide the reader from the creation to the Creator through the signs in the universe at the degree of witnessing it to strengthen the faith. In addition, Nursi establishes a new methodology of Qur'anic exegesis where scientific development can be used to further understand the meaning of verses in depth at the level of witnessing.

Third, to comment on a verse from the şuhudi perspective, it is necessary to have a degree of spiritual life in witnessing. For Nursi there is a degree of spiritual life that can lead to şuhudi interpretation. He says, "abandon your animalistic and corporeal being, enter the metaphysical world of the heart and soul. There you will then find an enormous 
realm of light, much superior to the materialistic world you assume to be vast ... " (Nursi 2007d, p. 164). To reach this degree, Nursi argues that there is a need for constant struggle for purifying the carnal soul (nafs), gaining marifa (gnostic knowledge) through "beseeching Almighty God, showing deep humility before Him, offering thanks, through impotence and want, and through self-sufficiency before the people" (Nursi 2010, p. 553). Mufassir (exegete) is a scholar and the "one who searches for truth should be like a diver, freed of the effects of time, able to dive into the depths of the past, weigh ideas on the scales of reason, and discover the source of everything" (Nursi 2008, p. 24).

Nursi divides life into two aspects, animalistic or corporeal being and metaphysical life. He categorises metaphysical life as relating to the heart and soul. The notion of the metaphysical world is subjective and highly difficult to attain. It involves a constant struggle to gain through ibadah (worship) and ubudiyyah (servitude), a high degree of sincerity, servanthood, and witnessing alongside knowledge. He argues that those who search every truth in corporeality cannot comprehend the metaphysical life and are blind to spirituality (Nursi 2008). For şuhudi interpretation, it is essential to have the intellectual capacity and satisfaction and zawq ruhani (spiritual joy) at the degree of metaphysical life. In his works, tafsiri şuhudi is not just an intellectual pursuit, it is an act and a process to be gained by internalising the Qur'anic truths and reflecting them into life through faith and sincere actions. In other words, if there is not a sound faith and spiritual life, it is not possible for an individual to understand the Qur'an, even if they are highly fluent in Arabic. Therefore, according to Nursian theology, it is impossible to experience spiritual witnessing without a sound faith and regular sincere good deeds.

According to witnesses and his students, Nursi would allocate about eight hours per day, including the last third of the night, to worship, dhikr (remembrance of God), and tafakkur (contemplation) with tears of suffering (Sahiner 2018). He was not allowed to have any books and could not access any libraries. As a result, most of his works are a product of suffering as well as recitation of the Qur'an, dua and dhikr in tears, devotion and loneliness.

Fourth, tafsiri şuhudi can be considered an offshoot of ishari tafsir injected with rationalism by visible things and experiments in the physical world. It also infuses spiritual witnessing into the dry body of scientific and modern tafsir that emerged after European enlightenment in the Muslim world. Nursi discusses scientific matters similar to the scientific tafsir, but he does not neglect to add its spiritual aspect. For example, on commenting on the verse "and the mountains as masts" (Qur'an, 78:7) (Unal 2008), he states that ordinary people see the benefit of mountains and offer thanks to the Creator. Geographers view the Earth as a sailing ship and the mountains as masts that give balance. They are amazed by such a magnificent creation and glorify God. (Nursi 2005).

Fifth, Nursi's tafsiri şuhudi is a product of mediative thinking which correlates the heart, mind, and soul with secular sciences. Tafsiri şuhudi is the result of witnessing God through His arts. Islamic philosophers witness with reason while Sufis witness with heart and soul. In tafsir şuhudi, God is witnessed with the heart and soul from the perspective of reason. For example, Nursi says:

Consider a fruit. It is a miniature of the whole tree, and its seed is like the page upon which the tree's life-history is inscribed. Also, it is connected with all members of its species as well as the whole Earth. Therefore, by virtue of the greatness of its art and meaning, the art of one fruit is as great as that of Earth. Thus, the One Who creates a fruit with all of its art and meaning can create and govern Earth. (Nursi 2007b, p. 48)

In tafsiri şuhudi, Nursi aims to prove the existence of the Creator by witnessing His creations at the degree of haqqal yaqin (the level of certainty) by employing reason without neglecting the heart and soul. Through tafsiri şuhudi, Nursi is not only addressing Muslims but also non-Muslims (Ozgel 2015). Having said that, Nursi also accepts the authority and validity of tafsir traditions (Çoruh 2019a), unlike other modernist mufassirs.

Sixth, in tafsiri şuhudi, he connects everything in the universe like pieces of a puzzle through Divine names. Thus, each piece is an interpreter of the connected piece. Nursi 
connects humans to everything in the universe through Divine names. He argues that every living creature reflects at least twenty Divine names (Nursi 2005). A human can comprehend the names of God and their manifestation in the universe at the degree of their spiritual witnessing. Therefore, for Nursi, tafsiri şuhudi is the main instrument for one to know their Creator. His transempirical exegesis demonstrates that "there is a harmony between the revelation of the Qur'an and the truth in the (furthest) regions of the Earth and in our souls. In this context, it is noteworthy that Nursi highlights that there is a union between the Qur'an and the universe" (Çoruh 2019a, p. 54). Consequently, it can be said that Nursi's şuhudi exegesis has brought a new breath and dynamism to the stagnated structure of linguistic or narration-based commentaries in the contemporary period. Nursi says,

"the Qur'an explains all such essential and important matters in a way befitting an All-Powerful One of Majesty, Who administers the universe like a palace, opens and closes the world and the Hereafter like two rooms, controls Earth like a garden and the heavens like a lamp-adorned dome, and in Whose sight the past and future are like day and night or two pages, and eternity like a point of present time". (Nursi 2005, p. 416)

Finally, one of the remarkable expressions in Nursi's works is the use of parables and allegories as a methodological principle of tafsiri şuhudi. He says, "I use metaphors and parables to ease comprehension and show how rational, proper, consistent, and coherent are the truths of Islam. The inner meanings are contained in the truths concluding them. Each story is like an allusion pointing to these truths. So, in this sense, they are not fictions but, rather, undoubted truths" (Nursi 2005, p. 67). However, he does not argue that his şuhudi interpretation is the absolute meaning of the verse that only God knows. Nursi believes each verse has a kulli mana (the absolute meaning that only God knows). He views his comment as a juz'i mana (a part of kulli mana) like capillaries of roots of a tree. It is not a full tree but part of a tree. Each scholar or mufassir explains a juz as part of the absolute meaning of the verse, not the whole meaning (Nursi 2010). On commenting on verse 31:27, he explains that the meaning (kulli mana) of God's words is inexhaustible.

In his şuhudi methodology, Nursi uses metaphors and parables to improve the comprehension of the verses. But some of his comments are still quite difficult to understand without having a background in Islamic knowledge. He also uses an eloquent Ottoman Turkish in his works, which is not easy to understand by the lay person and is difficult to translate into other languages. Although he addresses the heart, mind, and soul in his works, sometimes zavki ruhani or spiritual joys take over the reasoning. He departs from narrative based tafsirs in regard to Israiliyyat, which is a controversial issue among the Qur'anic exegetes (Albayrak 2000). He is critical of those who interpret the Qur'an according to Israiliyyat sources (Nursi 2008). Nursi views all tafsir books as a jewellery shop with pearls, gold, and silver but also believes there is wood, trash, and other worthless things amongst them (2008).

Nursi's tafsirs and the methodology can be considered an abstract of all types of tafsirs. He considers traditional tafsir methodology principles and does not depart from them totally. However, he does not repeat what other mufassirs wrote. As a bee collects pollen from different flowers and makes honey, Nursi benefited from all types of tafsirs, digested them, and then presented them into the tafsiri şuhudi according to the needs of the time. Although Nursi uses the term shuhud, which may not be objective rationality, he succeeds in rationalising it. Nursi's comments on verses appear philosophical compared with the traditional tafsirs. However, it should be considered şuhudi commentary due to its spiritual nature and philosophical construction (Çoruh 2019a). His tafsir constitutes the axis of the tafsir method he applies, which prioritises the meaning of the Qur'an rather than its wording. He described his tafsir as a spiritual tafsir, when referring to the exegetical methodology that he adopts (Ozgel 2015).

Nursi's commentary is more spiritual and rational-centric than literal. He summarises narratives, soul reason based, theological, and ishari tafsirs and presents them in his şuhudi 
way. Coruh argues that in his tafsiri şuhudi, Nursi "interprets the verse by visible events and experimental of the psychical world" (Çoruh 2019a, p. 54). By employing this methodology, Nursi wants to address various contemporary theological issues and speak to all humankind (Çoruh 2019a). He aims to demonstrate that the universe interprets the Qur'an or vice versa. Nursi argues that since the Qur'an is "Hutbe-i Ezeliyye" (the everlasting speech) and the universe is a manifestation of God's power, there must be harmony between the two rather than conflict. Therefore, tafsiri şuhudi is the interpretation of the Qur'an, the manifestation of God's attribute of kalam by cosmic signs that surrounded all people in the universe" (Çoruh 2019a, p. 55).

Even though Nursi aims to address the lay person, the Ottoman Turkish language he uses is difficult to understand. The eloquence of his writings and long paragraphs make it difficult for the reader to comprehend. In addition, due to scientific developments in the last 80 years, some of his scientific discussions in the first half of the 20th century are outdated, but this is out of the scope of this article. For example, based on the scientific discoveries of his time, Nursi indicates that the temperature at the crust of the Earth is 200,000 centigrade degrees (Nursi 1996). According to the latest scientific data, the Earth's core is 5200 centigrade degrees.

\section{Nursi's Şuhudi Interpretation of the Qalb Salim (Sound Heart)}

The word heart is mentioned 132 times in the Qur'an (Abd al-Baqi 1945) and has been widely discussed in the Quranic exegesis, particularly in ishari tafsirs. The Qur'an places the sound heart before offspring and wealth in the life hereafter to show its importance (Qur'an, 26:87-88). Nursi's interpretation of qalb salim is broader than other exegetical works. In this section, firstly, Nursi's şuhudi methodology of interpreting the verses related to sound heart will be examined. Then, his şuhudi interpretations of the heart in his works will be analysed.

Nursi maintains a balance between heart and mind in understanding the sound heart. He connects human beings to the universe through the sound heart in explaining the Divine names. The heart has two aspects. The first looks to the spiritual world and the second to the material world. For Nursi, the first one is connected to most creatures in the universe (Nursi 2010). To Nursi, "The heart is like a seed or the nucleus [of a person], and the brightest mirror of the Maker of creation" (Nursi 2007b, p. 102). That is, a heart is contained in an immaterial body formed of mysteries or the seed of an immaterial tree (Nursi 2007b). God "encoded a fig tree's future life in its tiny seed, and made the human heart a small-scale copy of thousands of worlds as well as a window opening onto them" (Nursi 2007a, p. 5).

Like many great scholars, Nursi also focuses on the understanding of the heart. He uses thirty-three types of expressions of the heart in his works, which is more than most well-known exegetical works. For example, al-Ghazali (d.1111) mentions nineteen types of the heart in his Magnum Opus Ihya-i Ulum al-Din (al-Ghazali 1993). Al-Qushayri indicates twenty types of the heart in his commentary of the Qur'an, Lataif al-Isharat (Al-Qushayri n.d.) and ar-Risalat al-Qushayriyya (al-Qushayri 2007). Imam Rabbani mentions twentyseven different types of expression for the heart (Imam Rabbani 2014). Nursi's use of different types of expressions for the heart more than the polymath scholars mentioned above highlights a remarkable difference of Nursi's şuhudi commentary. Nursi uses the following types of expressions in the context of commenting on the heart: sound and illumined heart, corrupted heart, soft heart, mirrorlike heart, private heart, collective hearts, weak hearts, pure-heart, unerring heart, troubled heart, wretched heart, outer heart, the most impotent heart, truth seeking heart, inner heart, blackened heart, skies of the heart, sealed heart, wounded heart, universal heart, common heart, wakeful heart, sincere heart, sick heart, eternity worshipping heart, easy heart, blessed heart, immaterial heart, weeping heart, and witnessing heart (Nursi 2005, 2007a, 2007b, 2010).

According to the Risale-i Nur, the sound heart is illuminated with Divine revelation. The soundness of the heart is reflected in social and spiritual life as sound reasoning and 
thinking, sound soul, sound emotion, sound idea, and fortress the sound nature. Therefore, a sound heart dominates a believer's perception, consciousness, reasoning, ethics, actions, and disposition (hal). This means that the limbs of a corporal body with a sound heart will act in righteousness, resembling the companion of the Prophet Muhammed. A sound heart with sincere good actions can lead to human perfection. A sound heart reflects its attributes in actions at the degree of Ihsan (excellence). At this degree, the sound heart is the window of the soul. The sound heart weeps with the eyes, travels with feet in the spiritual journey (Nursi 2005), hears with ears (Nursi 2010), and rules the desires of the carnal soul. Not only does the sound heart have a boundless capacity to love, but it can also contain the whole universe (Nursi 2009). Nursi relates the sound heart to sound reasoning (Nursi 2008). Such an illuminated heart is like a compass for guidance. He follows a spiritual path to detach the heart from anything that is an obstacle to gaining a sound heart. Nursi says, "the world is transitory, it is not worthy of the heart" (Nursi 2010, p. 104). The sound heart is in motion like everything in the universe and connected to everything from atoms to galaxies.

As the physical heart needs blood for life, the sound heart needs the light of revelation, reflection, and remembrance for satisfaction. Like al-Ghazali, Nursi correlates five external senses with the heart in regard to spiritual life. He argues that committing sins with any of the five external senses ruins the most subtle and inner faculties, including the heart (Nursi 2007b).

He uses comprehensive expressions and visible and experiential phenomena in regard to understanding the heart. When his works are examined, the place of the heart is more important than wealth and offspring. As mentioned above, he categorises human life into two levels, animalistic and corporal being, and the metaphysical, which is the world of the heart and soul. When the first one is abandoned, humankind will find an enormous realm of light, much superior to the materialistic world that is assumed to be vast.

In regard to spiritual aspects of the heart, including qalbi salim, Nursi was influenced by al-Ghazali in regard to connecting five external senses to the heart (al-Ghazali 2010). Seeing the heart as the place of knowledge and wisdom, he aligns with al-Qushayri (Al-Qushayri n.d.). For witnessing the heart, he was influenced by Imam Rabbani (Imam Rabbani 2014). However, he departed from these scholars by using more visible and physical things in light of reasoning. He also uses parables and contemporary science to elaborate spiritual aspects of the heart.

For the nourishment of the sound heart, Nursi asserts that reading the Qur'an will provide a sweet taste and satisfaction (Nursi 2007b). For Nursi, sincere actions, worship, contemplation, dua (supplication), dhikr (remembrance), and istighfar (asking forgiveness) are necessary for a sound heart. It can be said that a sound heart is in a state of contentment and peace.

Nursi's şuhudi interpretation of the heart is reflected in his life. Despite all oppressions, the tyranny of aggressive secularists, ultra nationalist, and some state assigned religious leaders' accusations, he never revolted and never asked his students or followers to revolt, but instead urged them to keep peace and security in the country (Sahiner 2018).

\section{Conclusions}

Scholars are called "ibn Zaman", the product of their times. Said Nursi witnessed the suffering of the Muslim world for different reasons. His works should be considered in such a context. Although his work Risale-i Nur is not a full tafsir, he responded to doubts created by materialistic philosophy about the existence of God, resurrection, prophethood, and justice. He developed a new methodology of tafsir, which he called "tafsiri şuhudi". This type of tafsir was coined for the first time by Nursi. He employed heart and mind with visible events and experiments in the physical world to gain transempirical knowledge. Although he validated traditional types of tafsirs and their methodologies, he added witnessing experience to the existing exegetical works with an infusion of rationalism. In addition, he used metaphors and parables to improve the comprehension of the verses. Tafsiri şuhudi is the result of witnessing God through His arts, beautiful names, and at- 
tributes that leads to the knowledge of God with aql, qalb, and soul. It can be said that the tafsiri şuhudi is an abstract of different types of tafsirs; the reader can find traditional and modern tafsirs in it.

This paper explained seven principles of tafsiri şuhudi. These principles are within the boundaries of Islamic aqidah and law. The aim is that through tafsiri şuhudi, the reader can reach tawhidi haqiqi, true faith, at the degree of certainty by witnessing the arts of God and understanding the wisdom behind them in a rational way. Şuhudi commentary can be experienced by abandoning the animalistic life and reaching the degree of the metaphysical life. Furthermore, this article shed light on tafsiri şuhudi. It also elaborated on Nursi's understanding of the sound heart. The topic of tafsiri şuhudi is scattered in Nursi's exegetical works and needs further research.

Funding: This research received no external funding.

Institutional Review Board Statement: Not applicable.

Informed Consent Statement: Not applicable.

Data Availability Statement: Not applicable.

Acknowledgments: I would like to thank retired Suat Yildirim for his valuable feedback for this article.

Conflicts of Interest: The authors declare no conflict of interest.

\section{References}

Abd al-Baqi, M. Fuad. 1945. Al-Mu'jam al-mufahras li-alfaz al-Qur'an al-Karim. Beirut: Dar al-Kutub al-Mișriyah.

Alam, Irshad. 2010. An Excerpt from the Maktubat-i Imam-i Rabbani. Dhaka: Aklima Akhtar.

Albayrak, Ismail. 2000. Qur'anic Narrative and Israiliyyat in Western Scholarship and in Classical Exegesis. Ph.D. thesis, Leeds University, Leeds, UK.

al-Ghazali, Abu Hamid. 1993. Ihya-I Ulum ad Din. Revival of Religious Learning. Translated by Fazl-ul-Karim. Karachi: Darul Ishaat. al-Ghazali, Abu Hamid. 2010. Wonders of the Heart. Translated by Walter James Skellie. Louisville: Fons Vitae.

al-Qushayri, Abu'l Qasim. 2007. Ar-Risalat al-Quhayriyya. Translated by Alexander D. Knysh. Lebanon: Garnet Publishing.

Al-Qushayri, Abu'l Qasim. n.d. Lataif al-Isharat. Amman: Royal aal al-Bayt Institute for Islamic Thought, Fons Vitae.

Ansari, Mahsheed. 2017. Nursi and Iqbal on Mi'raj: The Metaphysical Dimension of the Prophet's Ascension. Australian Journal of Islamic Studies 2: 21-41.

Çoruh, Hakan. 2019a. Modern Interpretation of the Qur'an: The Contribution of Bediuzzaman Said Nursi. London: Palgrave Macmillan.

Coruh, Hakan. 2019b. The Qur'ān and Interpretation in the Classical Modernism: Tafsircentric Approach of Muhammad 'Abduh'. Australian Journal of Islamic Studies 4: 1-21.

Faruque, Muhammad U. 2016. Sufism contra Shariah? Shāh Wal̄ Allāh's Metaphysics of Waḥdat al-Wujūd. Journal of Sufi Studies 5: 27-57. [CrossRef]

Imam Rabbani, F. Serhendi. 2014. Mektubat Tercumesi. Istanbul: Hakikat Kitabevi.

Keskin, Zuleyha. 2019. Inner Peace in the Life of Said Nursi. Australian Journal of Islamic Studies 4: 51-66.

Nursi, Said. 1996. The Letters. Translated by Sukran Vahide. Istanbul: Sozler Publications.

Nursi, Said. 2005. The Words. Translated by Huseyin Akarsu. Clifton: Tughra Books.

Nursi, Said. 2007a. Tarihce-i Hayat. Istanbul: Sahdamar Yayinlari.

Nursi, Said. 2007b. Al- Mathnawi al-Nuri. Translated by Husein Akarsu. Somerset: The Light.

Nursi, Said. 2007c. Signs of Miraculousness: The Inimitability of the Qur'an's Conciseness, rev. ed. Translated by Sukran Vahide. Istanbul: Sozler Publication.

Nursi, Said. 2007d. Mesnevi Nuriye. Istanbul: Sahdamar Yayinlari.

Nursi, Said. 2008. The Reasonings: A Key to Understanding the Qur'an's Eloquence. Somerset: Tughra Books.

Nursi, Said. 2009. Gleams. Translated by Huseyin Akarsu. Somerset: Tughra Books.

Nursi, Said. 2010. Rays Collections. Translated by Huseyin Akarsu. Somerset: Tughra Books.

Nursi, Said. n.d. Nur Aleminin bir Anahtari. Available online: https:/ / risaleoku.com/oku/nuralemi (accessed on 29 November 2021).

Ozgel, Ishak. 2015. Cağdaş tefsir yönelişleri açisindan Bediüzzaman Said Nursî́nin tefsir yöntemi (şuhûdî tefsir). Ekev Akademi Dergisi Yil: 19 Sayı 61: 299-321.

Saeed, Abdullah. 2008. The Qur'an: An Introduction. London: Taylor \& Francis Group.

Sahiner, Necmeddin. 2018. Son Sahitler. Istanbul: Nesil Yayinlari.

Saritoprak, Zeki. 2008a. Bediuzzaman Said Nursi in the Islamic World. Edited by Andrew Rippin. London and New York: Routledge, pp. 396-402. 
Saritoprak, Zeki. 2008b. Islam and Politics in the Light of Said Nursi's Writings. Islam and Muslim-Christian Relations 19: 113-27. [CrossRef]

Unal, Ali. 2008. The Qur'an with Annotated Interpretation in Modern English. Clifton: Tughra Books.

Vasquez, Manual A. 2011. More than Belief: A Materialist Theory of Religion. New York: Oxford University Press.

Weismann, Itzchak. 2007. The naqshbandiyya, Routledge Series of Sufism. Edited by Ian Richard Netton. New York: Routledge.

Yucel, Salih. 2017. Rumi: The Marriage of Heart and Mind in the Service of Spiritual Education. Transcendent Philosophy 18: 141-61.

Yucel, Salih. 2018. Serving Islam Peacefully during the Aggression and Said Nursi's Kalamisation of Positive Action for Social Harmony. Australian Journal of Islamic Studies 3: 53-67. 